\title{
Yesus Sebagai locus Classicus Sakramen Penguatan dalam Teologi Kenan B. Osborne
}

\author{
Antonius Hendri Atmoko a,1 \\ ${ }^{a}$ Universitas Sanata Dharma, Yogyakarta, Indonesia \\ ${ }^{1}$ chocho.aha@gmail.com
}

Keywords:

locus classicus,

Sakramen

Penguatan,

Kenan B. Osborne

\begin{abstract}
Most Christian believe that the Confirmation is the sacrament of the Holy Spirit (center of the sacrament) and the sacrament initiation. According to Kenan B. Osborne, such understanding of the Confirmation does not reach Jesus personally as the primordial sacrament and does not present Jesus as the locus classicus of Confirmation. Thus the understanding of people becomes a problem if there is no clear relationship between Jesus and the Holy Spirit in the Confirmation. Through literarature study, the writer uses Hans-Georg Gadamer's to dig deeper and to analyse the text and to fuse (fusion of horizons) the author's perspective. The results of the research are: 1) Kenan B. Osborne has a perspective that Jesus is as locus classicus of Confirmation, 2) We need a perspective of faith in the context of God's salvation in relationship with Trinitarian Theology to understand Jesus as locus classicus in related to pneumatology-christology, ecclesiology, and the understanding that Jesus as the primordial sacrament, 3) Osborne's idea completes and gives deeper understanding about Jesus as locus classicus of Confirmation in the teaching, the juridicial norms, and the pastoral approach of Catholic Church.
\end{abstract}

\section{PENDAHULUAN}

Sakramen Penguatan adalah satu dari tiga sakramen inisiasi Kristen, yaitu Baptis, Penguatan, dan Ekaristi. Melalui Sakramen Penguatan, umat beriman Kristiani menerima kepenuhan Roh Kudus sehingga mereka dapat secara penuh dan aktif berkarya dalam mewujudkan Kerajaan Allah sampai akhir zaman (Mat 28:18-20a), seperti halnya Yesus diutus Bapa untuk mewartakan Kerajaan Allah (Luk 4:18-19). ${ }^{1}$ Dalam Sakramen itu pula, penerima Sakramen Penguatan akan diurapi dengan minyak Krisma sebagai lambang pengudusan dan perutusan untuk melaksanakan tugas sebagai umat beriman, yaitu menjadi saksi Kristus dan membela iman (1Sam 10:1; 1Sam 16:13; 1Raj 1:39; bdk. LG 11, Surat Apostolik Divinae consortium naturae ${ }^{2}$ ).

Dewasa ini, banyak umat beriman Kristiani memahami Sakramen Penguatan sebagai sakramen pencurahan Roh Kudus dan sakramen kepenuhan inisiasi. Pemahaman umat yang demikian secara konkret penulis 
temukan ketika menjalani Tahun Orientasi Pastoral (TOP) di Paroki Hati Kudus Tuhan Yesus, Ganjuran, secara khusus ketika mendampingi para calon penerima Sakramen Penguatan. Pemahaman tersebut tentulah benar, akan tetapi fokus atau penekanan pada Yesus sebagai sakramen pokok tidak terlalu tampak atau tidak ditekankan dalam katekese penerimaan Sakramen Penguatan. Pemahaman yang diterima oleh umat ini menjadi suatu permasalahan bila relasi antara Yesus dengan Roh Kudus dihilangkan, dan pemahaman umat terhadap Sakramen Penguatan tidak sampai pada diri pribadi Yesus sebagai sakramen primordial atau sakramen pokok. Bertitik tolak dari konteks perjumpaan dan pengalaman inilah penulis berusaha untuk memahami dan menggali lebih dalam mengenai Sakramen Penguatan, secara spesifik lagi 'tempat' atau locus Yesus dalam Sakramen Penguatan.

Locus Yesus di dalam Sakramen Penguatan ini menjadi perhatian Kenan B. Osborne. ${ }^{3}$ Ia adalah seorang profesor Teologi Sistematik di Franciscan School of Theology dan Graduate Theological Union, Amerika. Melalui pemikirannya, Osborne semakin mengajak umat beriman Kristiani untuk kembali melihat titik pusat dari Sakramen Penguatan, yaitu Yesus sebagai sakramen primordial dan locus classicus. ${ }^{4}$ Menurut Osborne, Yesus merupakan locus classicus Sakramen Penguatan dan sekaligus sakramen induk atau pokok dari sakramen Gereja. Menurutnya, Yesus-lah yang hadir di tengah Gereja dalam Roh Kudus-Nya. ${ }^{5}$ Melalui Gereja, hadirlah Yesus yang menyelamatkan. Gereja hanya dapat menjadi sakramen kehadiran Allah oleh karena ada Roh Kudus. Roh Kuduslah yang mempersatukan Gereja dengan Yesus. Roh Kuduslah yang menghadirkan misteri Yesus dan karya-Nya yang menyelamatkan untuk sepanjang sejarah umat manusia. Hal ini berarti bahwa Yesus dengan seluruh pribadi dan karya-Nya serta bersama Roh Kudus menjadi tanda dan sekaligus menghadirkan Allah dalam kehidupan umat manusia. ${ }^{6}$ Dengan kata lain, bila umat beriman Kristiani membicarakan sakramen, maka pertama-tama mereka berbicara mengenai Yesus. Dengan demikian, umat beriman Kristiani perlu meninjau kembali teologi sakramen dan mengarahkan serta mendasarkan sakramen pada diri Yesus sebagai locus classicus Sakramen Penguatan.

Bila ditinjau dalam Alkitab, peranan dan relasi antara Roh Kudus dan pribadi Yesus tidak bisa dilepaskan dari relasi Trinitas. Di dalam Alkitab, kehadiran Roh Kudus mendeskripsikan dan menjelaskan identitas Yesus (Luk 1:35). Roh Kudus ini pulalah yang menyertai karya dan pelayanan Yesus. Dia pula yang diutus Yesus dalam mendampingi para murid setelah wafat dan kebangkitan-Nya. Bila dikaitkan dengan Sakramen Penguatan, peranan Yesus sebagai sakramen primordial dan peranan Roh Kudus tidak bisa dipisahkan. ${ }^{7}$ Hubungan atau relasi inilah yang akan diungkap oleh penulis dengan membuktikan bahwa Yesus memang locus classicus Sakramen Penguatan dan pandangan Osborne ini dapat dipertanggungjawabkan dalam ajaran dan teologi Gereja. Penulis menggunakan metode hermeneutika Hans-Georg Gadamer untuk menggali dan meneliti informasi atau data-data dari berbagai sumber tertulis yang mendukung tema, yaitu melalui proses membaca dan menganalisis teks, termasuk juga menyatukan atau meleburkan (fusion of horizons) cakrawala teks pengarang.

Dari pemaparan latar belakang penulisan ini, penulis mengambil hipotesis bahwa Yesus merupakan locus classicus dari 
Sakramen Penguatan. Maka penulis ingin mengulas, meneliti, dan menguji tesis teologi Osborne mengenai Yesus sebagai locus classicus Sakramen Penguatan dalam terang ajaran Gereja Katolik, yuridis dan pastoral.

\section{PEMIKIRAN KENAN B. OSBORNE TEN- TANG YESUS SEBAGAI LOCUS CLASSI- CUS SAKRAMEN PENGUATAN}

Kenan B. Osborne berpandangan bahwa sakramen bukanlah masalah upacara atau ritus yang berjumlah tujuh yang dimiliki oleh Gereja Katolik, tetapi pertama dan utama menunjuk pada diri Yesus sebagai sakramen pokok atau sakramen primordial. Melalui sakramen inilah realitas kasih Allah yang berpuncak pada diri Yesus hadir di dalam dan melalui tanda dalam perayaan liturgi. ${ }^{8}$ Dengan merayakan sakramen, umat beriman menghadirkan kembali realitas atau karya keselamatan Allah yang terjadi dan berpuncak dalam diri Yesus. Dengan kata lain, sakramen adalah dinamika karya keselamatan Allah yang hadir secara nyata dalam dan melalui Yesus, Sang Sakramen Pokok yang terjadi dalam sejarah hidup manusia.

Dalam gagasannya, Osborne selalu menjelaskan dan menekankan bahwa sakramen menunjuk pada diri Yesus sebagai sakramen pokok, termasuk dalam hal ini ialah Sakramen Penguatan. Oleh karena itu, maka Sakramen Penguatan ini semakin menemukan maknanya ketika mendasarkan pada diri Yesus sebagai sakramen pokok. Dengan kata lain, sakramen itu berpusat pada diri Yesus (kristosentris). Akan tetapi, karena Yesus dalam kemanusiaan-Nya adalah sakramen Allah, maka semua sakramen dan spiritualitasnya pada akhirnya bersifat teosentris. ${ }^{9}$ Sakramen Penguatan sebagai sakramen Yesus primordial ini dimaksudkan untuk men- yatakan bahwa sakramen itu ada karena Yesus. Yesus inilah locus classicus Sakramen Penguatan. Artinya, Yesus mempunyai 'tempat asali' dalam Sakramen Penguatan. Yesus menjadi bagian penting/pokok/dasar dari Sakramen Penguatan. ${ }^{10}$

Tema "Yesus sebagai sakramen pokok di dalam sakramen" merupakan tema yang hangat dibicarakan dalam diskusi teologi sakramen. Semmelroth, Karl Rahner, dan Schillebeeckx adalah para teolog yang memusatkan perhatian pada masalah Yesus sebagai sakramen pokok ini. Pemahaman Yesus sebagai locus classicus sakramen ini sangat penting bagi teologi Katolik dan praktik sakramen. Dalam Sakramen Penguatan, Yesus yang merupakan Sakramen Allah bukan hanya menjanjikan Roh Kudus bagi umat-Nya, tetapi Ia sendiri yang hadir dan tercurah bagi umat yang menerima sakramen ini. Sebagai Sakramen Allah, Ia hadir dan memberikan kekuatan iman bagi para penerima untuk bersedia menjadi pewarta dan saksi iman akan karya keselamatan Allah yang berpuncak dalam diri Yesus di dalam kehidupannya sehari-hari. Maka dari uraian tersebut dapat disimpulkan dan dipahami bahwa peristiwa pencurahan Roh Kudus di dalam Sakramen Penguatan bukanlah semata-mata hanya sebagai tanda Roh Kudus yang hadir. Lebih dari itu, peristiwa pencurahan Roh Kudus menjadi tanda hadirnya Allah dalam diri Yesus yang utuh - mencakup kemanusiaan dan keilahian-Nya -, yang mendayai para calon penerima Sakramen Penguatan untuk menjadi saksi Kristus. Jika Yesus adalah locus kehadiran Allah, sakramen primordial, fundamental, pokok, dan akar-sakramen, maka - hanya karena Yesus adalah sakramen - sakramen-sakramen pun kemudian menjadi sakramen. Dari sini dapat disimpulkan bahwa primordialitas mempunyai dua arah, yaitu 1) Yesus sebagai 
sakramen pokok dan memberi dasar sakramen, 2) Sakramen-sakramen menemukan ekspresinya secara penuh dalam diri Yesus. ${ }^{11}$

Secara ringkas, Kenan B. Osborne mempunyai pandangan bahwa Yesus adalah locus classicus Sakramen Penguatan. Dari pemikiran Kenan B. Osborne ini ada tiga hal yang menjadi poin penting, yaitu:

A. Sakramen Penguatan ialah Sakramen Roh Kudus dalam hubungannya dengan aspek kristologis. Artinya, Roh Kudus yang tercurah dalam Sakramen Penguatan terkait dengan unsur kristologis, di mana Yesus dimaknai bukan hanya setelah kebangkitan saja, akan tetapi secara keseluruhan, yaitu hidup, wafat, dan kebangkitan-Nya. Singkatnya, Roh Kudus yang tercurah dalam Sakramen Penguatan ini ialah Roh Kristus sendiri. Roh yang mendayai hidup, wafat, dan kebangkitan-Nya dalam menjalankan karya keselamatan Allah.

B. Yesus adalah pusat dan pokok asal semua sakramen. Yesus disebut sakramen pokok dan asal semua sakramen karena Yesus menjadi tanda dan simbol kehadiran Allah yang menyelamatkan manusia dan sekaligus menjadi tanda dan simbol Allah yang berkomunikasi dengan manusia. Oleh karena Yesus disebut sakramen pokok, maka sakramen-sakramen yang lain itu ‘ada' karena Yesus.

C. Gereja adalah sakramen Kristus. Kehadiran Roh di dalam Gereja itu dikarenakan Roh hadir dalam Kristus yang secara nyata hadir pula di dalam Gereja, termasuk dalam Sakramen Penguatan. Dalam Sakramen Penguatan, Roh Allah yang mendayai ke- manusiaan Yesus sebagai sakramen, tercurah dalam diri penerima dan mendayainya untuk menerima pelbagai karya atau tugas yang berguna untuk membarui Gereja dan menanggapi kebutuhan-kebutuhan Gereja. Dengan demikian Gereja menjadi tanda dan sarana kehadiran Yesus yang menyelamatkan.

Kesimpulan dari ketiga poin di atas ialah bahwa Sakramen Penguatan tidak boleh dipisahkan dari Yesus sebagai sakramen pokok. Selanjutnya, ketiga poin di atas akan penulis jadikan pisau analisa untuk membedah pemikiran Kenan B. Osborne dalam ajaran, norma-norma Yuridis, dan pedekatan pastoral Gereja Katolik

\section{YESUS SEBAGAI LOCUS CLASSICUS SAKRAMEN PENGUATAN DALAM TERANG AJARAN GEREJA KATOLIK}

Pembahasan pada bagian ini masih merupakan kesinambungan dari pemikian Osborne. Pada bagian ini, pemikiran Osborne diterangi dengan ajaran Gereja Katolik. Maksud dari bagian ini ialah untuk melihat kesinambungan dan relasi pemikiran Osborne dengan Ajaran Gereja Katolik. Menurut Osborne, Yesus hadir dan menjadi sakramen Allah melalui Gereja-Nya. Ia hadir dalam sakramen-sakramen, termasuk Sakramen Penguatan.

Dari awal sejarahnya hingga sekarang, Sakramen Penguatan tidak bisa dilepaskan dari sakramen inisiasi. Inisiasi, dari kata Latin inire atau initiare, berarti memasuki, masuk, atau bergabung ke dalam suatu kelompok; memasukkan atau menerima seseorang ke dalam suatu kelompok. ${ }^{12}$ Inisiasi di dalam Gereja merupakan sakramen karunia keselamatan. Adapun tahap-tahap utama inisiasi Gereja tampak dalam Sakra- 
men Baptis, Penguatan, dan Ekaristi Pertama. Sejak awal orang dipanggil untuk hidup bersama dengan Allah dan sesama. Kebersamaan dengan Allah yang dianugerahkan kepada manusia melalui Yesus dan hadir dalam Gereja berkat Roh Kudus merupakan karunia. Dengan menerima Baptisan, Penguatan, dan Ekaristi, seseorang menerima anugerah keselamatan, yakni kebersamaan dengan Allah. ${ }^{13}$

Sejak awal Kekristenan, Gereja telah merayakan inisiasi bagi orang-orang yang bertobat dan orang-orang baru yang hendak masuk ke dalam komunitasnya melalui proses sakramental yang dipandang sebagai Baptisan - (Penguatan) - Ekaristi. Baptisan-Ekaristi benar-benar merupakan sakramen inisiasi ke dalam Gereja Kristen dan proses ini jelas terlihat dalam ritus pembaptisan yang baru di Gereja Katolik setelah Konsili Vatikan II, khususnya dalam The Rite of Christian Initiation of Adults (RCIA). ${ }^{14}$ RCIA dengan jelas menyajikan sakramen inisiasi ini, yaitu mulai dengan pemanggilan calon baptis (220-222), kemudian upacara urapan setelah baptis (224), memakai pakaian putih (225), penerimaan lilin menyala (226), lalu dilanjutkan dengan perayaan penguatan (227-231). Setelah penguatan ada kolekte, dan diakhiri dengan Ekaristi. ${ }^{15}$

Menurut sejarahnya, konsep inisiasi sebagai praktek dan gagasan sudah ada sejak Gereja Perdana. Hal itu tampak dalam penerimaan seseorang masuk ke dalam Gereja dengan pembaptisan, penumpangan tangan, dan Ekaristi. Namun praktek ini belum seragam. Di dalam Perjanjian Baru, tindakan penumpangan tangan dihubungkan dengan pencurahan Roh Kudus (Kis 8:14-17; 19:1-7). Di sini penumpangan tangan menandai kapan seseorang benar-benar diterima ke dalam Gereja apostolik. Oleh karenanya penumpangan tangan ini dilakukan oleh para rasul sendiri, sebagai tanda penerimaan orang-orang Kristen baru ke dalam pangkuan Gereja para rasul. ${ }^{16}$

Penumpangan tangan menyimbolkan bahwa daya ilahi disalurkan dari sumbernya kepada orang tertentu. Dengan penumpangan tangan orang diberkati. Artinya, barakah ilahi, daya hidup, dan penyelamatan disalurkan kepada seseorang, sehingga ia mendapat hidup dan damai (syaloom). Pengurapan dengan minyak ini juga dapat menyimbolkan hal yang sama, yaitu daya ilahi disalurkan kepada seseorang, misalnya untuk menyanggupkan dia memegang tugas sakral tertentu ataupun untuk penyembuhan orang sakit. Oleh karena kata Yunani khrinein menjadi gelar atas nama diri Khristos (ham-masyiah: yang diurapi), maka pengurapan dengan minyak (krisma) dapat menyimbolkan bahwa orang secara pribadi diserupakan dengan Yesus. Itulah sebabnya mengapa dalam perkembangan upacara inisiasi Kristen muncul penumpangan tangan dan pengurapan minyak. ${ }^{17}$

Pada abad pertengahan, perkembangan ritus yang populer adalah pengurapan dengan minyak daripada penumpangan tangan. Kemudian pada masa Skolastik, tidak ada lagi unsur penumpangan tangan. Santo Thomas Aquinas, misalnya, hanya mengenal pengurapan minyak sebagai satu-satunya inti liturgi penguatan. Hal ini diteguhkan dalam Konsili Florenz pada tahun 1439 (DS 1317) ${ }^{18}$, ajaran Paus Innocentius III pada akhir abad XV, dan juga Konsili Trente (DS 1629). ${ }^{19}$ Kemudian pada abad XVIII, Paus Benedictus XIV mulai menyatukan kembali penumpangan tangan dan pengurapan minyak. Konsili Vatikan II dan ritus penguatan yang baru menegaskan kembali bahwa inti upacara penguatan terletak pada penump- 
angan tangan dan pengurapan minyak, di mana Uskup (Imam) mengucapkan forma, "Terimalah tanda karunia Roh Kudus."20 Mulai abad XI hingga sekarang, ketiga sakramen - Baptis, Penguatan, dan Ekaristi - dipandang sebagai satu kesatuan inisiasi dengan praktek penerimaan yang terpisah. Hal ini tampak dalam Konstitusi Sacrosanctum Concilium (SC) 71 dan Kitab Hukum Kanonik (KHK) 1983 kanon 842 \$2.21 Oleh karena itu, dalam keterangan-keterangan selanjutnya, Konsili Vatikan II biasanya menyebut baptisan dan penguatan secara bersama-sama, serta menghubungkan penguatan dengan Roh Kudus (LG 11, 33; AG 11; AA 3). Dalam hal ini baptisan juga tetap dihubungkan dengan Roh Kudus (SC 6). Mengenai Sakramen Penguatan, Konsili Vatikan II mengajarkan demikian: Berkat Sakramen Penguatan, mereka terikat pada Gereja secara lebih sempurna, dan diperkaya dengan kekuatan Roh Kudus yang istimewa. Dengan demikian, mereka semakin diwajibkan untuk menyebarluaskan dan membela iman sebagai saksi Kristus yang sejati dengan perkataan dan perbuatan (LG 11). Akhirnya, dalam Ekaristi, keanggotaan kita pada Tubuh Kristus mencapai kesempurnaannya (PO 5).

Dokumen Konsili Vatikan II tidak secara langsung menjelaskan mengenai Yesus sebagai locus classicus dalam Sakramen Penguatan, sebab beberapa dokumen hanya menyebut Sakramen Penguatan sebagai sakramen pencurahan Roh Kudus dan tidak menjelaskan secara rinci mengenai Yesus yang hadir dalam sakramen tersebut. Lebih dari itu, Dokumen Konsili Vatikan II juga tidak banyak menjelaskan mengenai Sakramen Penguatan ini. Bagi penulis, pemahaman mengenai Sakramen Penguatan sebagai sakramen pencurahan Roh Kudus (LG 11) seperti halnya dijelaskan dalam Dokumen
Konsili Vatikan II, tentulah benar. Namun bagi penulis, pemahaman ini perlu diperdalam sampai pada akarnya, yaitu pada diri Yesus sebagai sakramen pokok. Tanpa adanya Yesus sebagai sakramen pokok, maka sakramen-sakramen tidak punya makna sama sekali. Sakramen mempunyai eksistensinya oleh karena Yesus sebagai sakramen pokok. Dengan pemahaman yang matang mengenai Sakramen Penguatan, orang-orang akan semakin paham bahwa Roh Kudus yang tercurah dalam Sakramen Penguatan adalah Roh Yesus dan Roh Allah; Roh Kudus yang satu dan sama. ${ }^{22}$

Berkenaan dengan Yesus sebagai locus classicus Sakramen Penguatan dalam terang ajaran Gereja, penulis juga menggunakan dua ensiklik, yaitu Divinum Illud Munus dan Dominum et Vivificantem. Ensiklik Divinum Illud Munus dipromulgasikan oleh Paus Leo XIII pada tanggal 15 Mei 1897. Sedangkan ensiklik Dominum et Vivificantem dipromulgasikan oleh Paus Yohanes Paulus II pada tanggal 16 Mei 1986. Kedua ensiklik ini memang tidak secara langsung membicarakan mengenai Sakramen Penguatan, namun dua ensiklik ini kiranya membantu kita semua dalam menemukan locus Yesus dan hubungan Yesus dengan Roh Kudus dalam Sakramen Penguatan.

Ensiklik Divinum Illud Munus berisi dan menjelaskan mengenai kehadiran dan kuasa Roh Kudus. Kehadiran Roh Kudus ini tak lepas dari karya keselamatan Bapa yang berpuncak pada diri Yesus. Tugas perutusan ilahi yang diterima Yesus dari Bapa-Nya untuk kesejahteraan seluruh umat manusia - yang dipenuhi-Nya dengan sempurna - memiliki tujuan akhir untuk menempatkan manusia kepada kehidupan abadi dan mulia, serta menjaga mereka supaya tetap berada dekat dengan rahmat ilahi. Sebelum 
kenaikan-Nya ke surga, Ia menjanjikan Roh Penghibur kepada para murid. Roh Kudus tersebut secara setara diutus - dan karena itu berasal dari diri-Nya dan Bapa - untuk memenuhi tugas-Nya sebagai Pengantara, Penghibur, dan Guru, serta melaksanakan karya yang telah dimulai oleh Kristus sendiri dalam hidup duniawi-Nya (art. 1). Peristiwa Pentakosta tidak ditujukan semata untuk menghormati Roh Kudus sendiri, tetapi untuk mengenangkan kedatangan-Nya, atau misi eksternal-Nya (art. 3). Hubungan Trinitaris dalam peristiwa Pentakosta perlu juga diperhatikan. Dari ensiklik ini, jika kita hubungkan dengan Sakramen Penguatan, maka tampak bahwa pencurahan Roh Kudus dalam Sakramen Penguatan merupakan peristiwa hadirnya Yesus sendiri yang memampukan para calon penerima Sakramen Penguatan semakin dewasa dalam iman dan juga menjadi bentara Kristus di dunia ini dalam mewartakan Kabar Gembira. Maka melalui penjelasan ini semakin tampak dan jelaslah locus Yesus dan peran-hubungan Roh Kudus dengan Yesus dalam Sakramen Penguatan.

Sama halnya dengan ensiklik Divinum Illud Munus, ensiklik Dominum et Vivificantem tidak secara langsung membahas mengenai Sakramen Penguatan, namun dapat membantu kita memahami hubungan Yesus dengan Roh Kudus. Bila dikaitkan dengan Sakramen Penguatan, maka pembahasan ini tak lepas dari kesatuan Bapa, Putera, dan Roh Kudus yang hadir dalam sakramen tersebut, sebab di sini perlu dipahami bahwa sakramen merupakan tanda nyata karya keselamatan Allah bagi manusia. Yesus menubuatkan kedatangan-Nya sebagai penasihat yang lain yang karena merupakan Roh Kebenaran akan memimpin para Rasul dan Gereja kepada semua kebenaran (Yoh 16:13). Hal ini akan terlaksana berdasarkan hubungan khusus antara Roh Kudus dan Kristus: "Ia akan memberitakan kepadamu apa yang diterimanya daripada-Ku (Yoh 16:14). Persatuan ini mempunyai sumber aslinya di dalam Bapa. Oleh karena berasal dari Bapa, Roh Kudus diutus oleh Bapa (Yoh 14:26; 15:26). Roh Kudus pertama-tama diutus sebagai karunia bagi Putera, yang menjadi manusia, untuk memenuhi ramalan-ramalan mengenai Mesias (art. 22). Dalam hal ini tidak ada pengutusan Roh Kudus tanpa salib dan kebangkitan (Yoh 16:7). Roh Kudus yang tercurah pada hari Pentakosta inilah yang kemudian menguduskan Gereja selama-lamanya, yang tampak dalam Sakramen-Sakramen, secara khusus Sakramen Penguatan.

Sakramen Penguatan secara tegas dan eksplisit membuat Roh Kudus menjadi tampak sebagai kekuatan Gereja. Gereja itu memberi wujud historis kelihatan kepada tugas dan karya publik Kristus, yang tertuju kepada seluruh dunia. Selain itu, dalam Sakramen Penguatan, Roh Kudus menyanggupkan orang yang menerima sakramen ini untuk secara aktif turut serta dalam tugas misioner dan publik jemaat Kristen. Dengan demikian, Sakramen Penguatan tidak menambah apa-apa pada realitas yang diekspresikan dalam inisiasi, yang terdiri atas baptisan dengan air. Roh Kudus tidak 'tambah', tetapi Sakramen Penguatan menambah pada ekspresi realitas yang sama. Ekspresi tambahan itu bukanlah hampa dan kosong, sebab pada Roh Kudus ada segi eklesial dan misioner, yang terungkap dalam Sakramen Penguatan. Dalam sakramen inilah segi Roh Kudus (pneumatologis) mendapat wujud historisnya. ${ }^{23}$ Dari uraian tersebut, jika memakai pisau analisa pemikiran Osborne, maka dapat disimpulkan bahwa ajaran teologis mengenai Sakramen Penguatan dan perkembangannya tidak bisa dilepaskan dari 
unsur Roh Kudus atau aspek Pneumatologis. Meski demikian, kehadiran Yesus sebagai locus classicus di dalam dan melalui Roh Kudus tidak boleh dilepaskan dari aspek kristologis, yaitu Yesus sendiri sebagai sakramen pokok dan puncak dari karya keselamatan Allah, mulai dari hidup hingga kebangkitan-Nya. Kehadiran dan penyertaan Yesus ini tidak hanya terhenti sampai pada peristiwa kebangkitan-Nya. Setelah kebangkitan-Nya, Ia melalui Roh Kudus-Nya hadir dan menyertai Gereja-Nya. Adapun Roh Kudus yang Ia curahkan ialah Roh-Nya sendiri, yang kehadiran-Nya sebagai sakramen Allah tampak dalam sakramen-sakramen Gereja. Singkatnya, kehadiran Yesus sebagai locus classicus di dalam dan melalui Roh Kudus dalam Sakramen Penguatan merupakan tanda kehadiran dan karya keselamatan Allah bagi manusia.

\section{YESUS SEBAGAI LOCUS CLASSICUS SAKRAMEN PENGUATAN DALAM TIN- JAUAN YURIDIS DAN PASTORAL}

Pada bagian ini penulis akan menggunakan intisari atau inti pokok dari pandangan teologis Osborne mengenai Yesus sebagai locus classicus Sakramen dengan menganalisisnya dalam terang ajaran Gereja Katolik (sebagaimana sudah dijelaskan pada bagian sebelumnya) untuk membuat relevansi dan terobosan pastoral masa kini. Tinjuan yuridis dan pastoral dipakai untuk memberikan terobosan pastoral praksis (isi) dalam katekese persiapan Sakramen Penguatan. Adapun tinjauan yuridis yang penulis pakai ialah berkenaan dengan hakikat (kan. 879), perayaan (kan. 880-881), pelayan (kan. 882-888), calon (kan. 889-891), dan bapak/ibu Sakramen Penguatan (kan. 892-893). Pada bagian yuridis ini penulis tidak akan memberikan pemahaman detail masing-masing kanon, tetapi penulis hen- dak melihat kanon-kanon tersebut secara umum dalam kaitannya dengan Yesus sebagai locus classicus Sakramen Penguatan.

Dalam kanon-kanon tersebut (kan. 879893), Yesus sebagai locus classicus Sakramen Penguatan memang tidak secara eksplisit dijelaskan. Locus Yesus di dalam tinjuan yuridis dapat kita ketahui dengan memakai kacamata iman hubungan Trinitaris dalam Sakramen Penguatan dan tentunya dengan menggunakan aspek-aspek pneumatologis-kristologis, eklesiologis, dan pemahaman akan Yesus sebagai sakramen primordial, sebagaimana yang menjadi inti pemikiran dari Osborne. Dengan demikian, bertitik tolak dari tiga hal yang menjadi poin penting pemikiran Osborne, - yaitu: 1) Sakramen Penguatan ialah Sakramen Roh Kudus dalam hubungannya dengan aspek kristologis, 2) Yesus adalah pusat dan pokok asal semua sakramen, 3) Gereja adalah sakramen Kristus -, dan juga diterangi dengan ajaran Gereja Katolik, maka muncullah gagasan, masukan, ataupun saran terkait dengan pastoral katekese Sakramen Penguatan.

Bagi penulis, pemikiran Osborne ini memberikan masukan yang berharga dalam perkembangan teologi Sakramen Penguatan. Dengan menjadikan tema Yesus sebagai locus classicus Sakramen Penguatan sebagai materi yang diberikan dalam katekese, fokus atau poin pemahaman yang diterima oleh para calon penguatan akan lebih lengkap. Dari pembahasan ini dapat disimpulkan bahwa Yesus sebagai locus classicus menjadi dasar pastoral katekese Sakramen Penguatan. Materi mengenai Yesus sebagai locus classicus Sakramen Penguatan menjadi dasar pastoral katekese karena materi ini menjadi hal yang fundamental atau mendasar yang perlu dipahami dan dihayati 
oleh umat beriman kristiani, secara khusus para calon penerima penguatan. Dengan demikian, umat beriman kristiani akan semakin memahami bahwa Roh Kudus yang tercurah dalam Sakramen Penguatan merupakan Roh Kristus sendiri yang hadir dan menguatkan penerima untuk siap menjadi saksi sekaligus pewarta Injil-Nya. Maka, sejalan dengan Osborne, penulis berpendapat bahwa perlu adanya pastoral katekese yang mendalam sehingga ada transformasi nyata dalam pemahaman tentang Yesus sebagai sumber dan inti sakramen Kristen. Namun yang perlu dicatat dalam hal ini ialah bahwa bukan berarti materi dan silabus katekese Sakramen Penguatan yang selama ini digunakan tidak relevan, melainkan justru pemikiran Osborne ini semakin melengkapi ajaran Gereja Katolik dan juga katekese yang selama ini dipakai dalam pendampingan calon penguatan. Lewat katekese ini, Gereja hendaknya bisa membantu umat agar semakin memahami, menghayati, dan mewujudkan imannya dalam kehidupan sehari-hari.

Dalam memberikan terobosan pastoral, penulis memakai tiga sampel buku katekese Sakramen Penguatan yang selama ini digunakan dalam pendampingan calon penguatan di Keuskupan Agung Semarang (KAS). Ketiga buku tersebut antara lain: 1) Katekese Inisiasi: Gagasan Dasar dan Silabus (Komisi Kateketik KAS), 2) Persiapan Krisma Suci (Ernest Mariyanto), dan 3) Katekese bagi Calon Krisma (Aloysius Soenarto, dkk). Sekali lagi, ketiga buku ini hanyalah sampel, dan tidak menutup kemungkinan dengan adanya beberapa buku lain yang dipakai di beberapa Paroki. Melalui ketiga buku tersebut penulis hendak menganalisis dan sekaligus memberikan masukan terkait ada tidaknya materi yang menerangkan dan menjelaskan mengenai Yesus sebagai locus classicus Sakramen Penguatan. Dari proses inilah kemudian penulis menemukan terobosan pastoral berkenaan dengan katekese persiapan penerimaan Sakramen Penguatan.

Secara umum, buku-buku katekese yang dipakai dalam proses pendampingan calon penguatan tersebut sudah bagus, bahkan sudah dilengkapi dengan silabus yang jelas dan komplit. Kini tinggal bagaimana materi katekese tersebut diterapkan dan dioptimalkan. Penulis merasa bahwa bukubuku tersebut cukup membantu pembaca maupun para katekis untuk memberikan materi bagi para calon penguatan. Setelah menganalisis dan mencermati isi/materi dari buku-buku tersebut, ditemukan bahwa pemahaman mengenai Yesus sebagai locus classicus Sakramen Penguatan tidak eksplisit dijelaskan. Sebagian besar buku tesebut lebih menjelaskan mengenai Sakramen Penguatan sebagai sakramen pencurahan Roh Kudus dan bagaimana Roh Kudus tersebut berperan dan mendayai para calon penguatan. Buku-buku tersebut tidak memberikan penjelasan sampai pada Yesus sebagai locus classicus Sakramen Penguatan dan tidak sampai pada pemahaman bahwa Roh Kudus yang tercurah dalam Sakramen Penguatan ialah Roh Kristus sendiri, Roh yang juga diberikan-Nya kepada para rasul saat Pentakosta.

Bertitik tolak dari analisis buku-buku katekese tersebut, yang tentunya diterangi dengan intisari pemikiran Osborne dalam terang Ajaran Gereja Katolik dan yuridis, maka terobosan pastoral yang hendak penulis tawarkan lebih pada optimalisasi dan dimasukkannya materi mengenai Yesus sebagai locus classicus Sakramen Penguatan sebagaimana yang menjadi pemikiran Osborne di dalam buku-buku katekese yang 
ada (dari segi isi maupun teknis penyampaian katekese). Misalnya, pada bagian tema berkenaan dengan Sakramen Penguatan, terlebih dalam peran Roh Kudus dan kaitannya dengan Yesus, bisa dijelaskan lebih detail lagi mengenai Yesus sebagai locus classicus Sakramen Penguatan. Intisari dari pemikiran Osborne yang diterangi oleh ajaran Gereja Katolik yang sudah dibahas pada tulisan ini bisa dipakai dan digunakan untuk semakin memperdalam bahan atau materi. Penambahan materi dan juga optimalisasi buku-buku katekese yang sudah ada akan semakin menambah pemahaman bagi para calon penerima Sakramen Penguatan, para katekisnya, maupun orang yang membacanya. Adapun poin yang terpenting ialah bahwa katekese ini bisa mengajarkan dan mengembangkan iman, secara khusus calon penguatan ini bisa semakin memperdalam dan menghayati Yesus sebagai sakramen pokok dan locus classicus Sakramen Penguatan.

Dalam katekese Sakramen Penguatan, para pendamping (katekis) perlu memberikan pemahaman dan penyadaran pada para calon akan panggilan dan perutusan sebagai saksi Kristus. Pendekatannya ialah menggunakan pendampingan terstruktur mengenai sakramen inisiasi, mengenalkan tugas-tugas Gereja di tengah masyarakat dan meneguhkan peranan Roh Kudus dalam hidup orang Katolik kepada para calon. Pada bagian ini, penulis mengusulkan terobosan pastoral, yaitu optimalisasi buku-buku katekese yang ada dengan menambahkan materi mengenai Yesus sebagai locus classicus dalam hubungannya dengan peranan Roh Kudus di dalam Sakramen Penguatan. Para pendamping atau katekis bisa menjelaskan dan menguraikan tema Yesus sebagai locus classicus Sakramen Penguatan melalui beberapa sub tema, misalnya: Yesus sebagai sakramen pokok, Yesus sebagai locus classicus di da- lam kemanusiaan-Nya, Yesus sebagai locus classicus kehadiran Allah yang pokok, dan Yesus sebagai locus classicus ditinjau dalam aspek pneumatologis-kristologis serta eklesiologis. Dengan demikian, para calon diharapkan dapat memahami makna sakramen inisiasi, memahami peran Roh Kudus, dan memahami tugas perutusan Gereja di tengah masyarakat. Lebih dari itu, para calon semakin memahami kehadiran Yesus di dalam Sakramen Penguatan sebagai locus classicus.

Kemudian, setelah materi atau isi mengenai Yesus sebagai locus classicus Sakramen Penguatan ditambahkan dalam buku katekese, para katekis kemudian berperan untuk menyampaikan materi tersebut dengan baik, yaitu bukan hanya monolog tetapi ada dialog, sehingga para calon penerima mempunyai peran aktif (ada interaksi) dalam memahami materi. Selain itu, dalam penyampaian materi, para katekis bisa mengemasnya secara menarik dengan menggunakan media informasi yang sesuai (kontekstual), misalnya: bisa memanfaatkan laptop atau komputer untuk menampilkan power point yang menarik dan mendalam, menggunakan film-film ilustrasi yang bisa mewakili tema/ materi yang hendak disampaikan, adanya permainan atau kuis, penggunakan media gambar, dan lain sebagainya. Penggunaan media-media modern ini bukan semata supaya tidak ketinggalan zaman, namun lebih dari itu supaya semakin membantu para calon penguatan dalam proses pembelajaran dan pemahaman materi. Lebih dari itu, materi tersebut bisa dikemas dengan kegiatan yang menarik, seperti outbond, dan mengajak para calon untuk merefleksikan kembali pengalaman perjumpaan mereka dengan Yesus sendiri. Melalui kesaksian iman dan kesaksian hidup ini, mereka akan semakin diteguhkan bahwa dirinya mempunyai bekal 
rohani akan pengalaman perjumpaan dengan Yesus sebagai sakramen pokok dan sekaligus sakramen kehadiran Allah. Harapannya, ketika para calon ini mempunyai bekal pengalaman iman akan Yesus, maka mereka akan lebih siap dan kuat dalam menjadi saksi Kristus, sebagaimana yang menjadi tujuan dari Sakramen Penguatan.

\section{KESIMPULAN}

Melalui pembahasan pemikiran Kenan B. Osborne dan diterangi dengan ajaran Gereja Katolik, seperti ajaran Konsili Vatikan II, ensiklik Divinum Illud Munus, ensiklik Dominum et Vivificantem, dan ditinjau pula dalam terang norma yuridis dan pastoral, penulis menyimpulkan bahwa Yesus memang merupakan locus classicus dari Sakramen Penguatan. Pernyataan ini dapat dibuktikan dengan beberapa dasar dan kesimpulan sebagai berikut:

a) Kenan B. Osborne mempunyai pandangan bahwa Yesus merupakan locus classicus Sakramen Penguatan. Dari pemikiran Kenan B. Osborne ini ada tiga hal yang menjadi poin penting, yaitu: 1) Sakramen Penguatan ialah Sakramen Roh Kudus dalam hubungannya dengan aspek kristologis. Artinya, Roh Kudus yang tercurah dalam Sakramen Penguatan ini ialah Roh Kristus sendiri. Roh yang mendayai hidup, wafat, dan kebangkitan-Nya dalam menjalankan karya keselamatan Allah. 2) Yesus adalah pusat dan pokok asal semua sakramen. Yesus disebut sakramen pokok dan asal semua sakramen karena Yesus menjadi tanda dan simbol kehadiran Allah yang menyelamatkan manusia dan sekaligus menjadi tanda dan simbol Allah yang berkomunikasi dengan manusia.
3) Gereja adalah sakramen Kristus. Kehadiran Roh di dalam Gereja itu dikarenakan Roh hadir dalam Kristus yang secara nyata hadir pula di dalam Gereja, termasuk dalam Sakramen Penguatan. Dengan demikian Gereja menjadi tanda dan sarana kehadiran Yesus yang menyelamatkan. Dari ketiga poin tersebut, dapat ditarik kesimpulan bahwa Sakramen Penguatan tidak boleh dipisahkan dengan Yesus sebagai locus classicus.

b) Dalam sejarah Sakramen Penguatan hingga perkembangan teologis saat ini, memang Yesus sebagai locus classicus dalam sakramen tersebut tidaklah terlalu tampak atau ditekankan. Hal ini karena memang pemahaman-pemahaman dari awal yang diterima oleh umat tidak terlalu mengakar dan tidak sampai pada Yesus sebagai sakramen pokok. Pada dasarnya dokumen atau ajaran-ajaran Gereja Katolik, seperti dalam Dokumen Konsili Vatikan II, dan atau ensiklik/surat/dokumen, telah sedikit banyak membicarakan mengenai Sakramen Penguatan. Namun untuk bisa memahami Yesus sebagai locus classicus Sakramen Penguatan, kita perlu memakai kacamata iman dalam konteks karya keselamatan Allah dalam hubungan Trinitaris. Tentunya aspek-aspek pneumatologis-kristologis, eklesiologis, dan pemahaman akan Yesus sebagai sakramen primordial perlu mendapat penekanan secara lebih.

c) Melalui penelitian ini, penulis menemukan kesinambungan antara pemikiran Kenan B. Osborne dengan ajaran Gereja Katolik. Artinya, pemikiran Kenan B. Osborne semakin melengkapi dan memberikan pemahaman men- 
dalam mengenai Yesus sebagai locus classicus Sakramen Penguatan di dalam ajaran Gereja Katolik. Sebaliknya, ajaran Gereja Katolikjuga memberikan dasar-dasar pemahaman sakramen dan juga sisi peran relasi Roh Kudus dengan Yesus (aspek pneumatologis-kristologis) bagi pemikiran Kenan B. Osborne. Selain itu, kesinambungan dari pemikiran Kenan B. Osborne dalam terang ajaran Gereja Katolik ini juga selaras dengan norma-norma yuridis Sakramen Penguatan yang termuat dalam Kitab Hukum Kanonik. Melalui norma ini, pemikiran Kenan B. Osborne sesuai dengan pemahaman, aturan, dan perayaan Sakramen Penguatan. Dari semua penemuan ini lahirlah harapan dalam diri penulis agar Gereja dapat menggunakan pemikiran Kenan B. Osborne ini sebagai salah satu bahan atau materi pastoral katekese bagi calon penguatan. Dengan demikian mereka akan dibantu untuk semakin mendalami makna Sakramen Penguatan, secara khusus mendalami Yesus sebagai locus classicus Sakramen Penguatan. Melalui hasil dari penelitian ini pula, kita bukan hanya berhenti pada pembuktian akan kesinambungan antara pemikiran Kenan B. Osborne dan ajaran Gereja Katolik berkaitan dengan Yesus sebagai locus classicus Sakramen Penguatan, namun juga dapat menemukan pencerahan dan pembelajaran mengenai refleksi iman akan Yesus sebagai sakramen pokok. Harapannya, dengan adanya keselarasan dan juga pemahaman yang mendalam dari pemikiran Kenan B. Osborne di dalam terang ajaran Gereja Katolik dan norma yuridis, Gereja semakin dibantu untuk membuat terobosan pastoral katekese pendampingan calon penguatan yang lengkap, mendalam, dan kontekstual.

Secara garis besar, pemikiran Kenan B. Osborne dalam terang ajaran, norma-norma yuridis, dan pedekatan pastoral Gereja Katolik ini merupakan tema yang masih relevan untuk dipelajari, didiskusikan, dan dikembangkan. Adapun asalan bahwa pemikiran Osborne ini masih relevan untuk dikembangkan dan dibahas ialah pemikiran Osborne ini semakin memperdalam pemahaman secara utuh mengenai Sakramen Penguatan, secara khusus berkaitan dengan Yesus sebagai locus classicus. Pemikiran Osborne ini menjadi relevan di tengah minimnya buku-buku, katekese, maupun bahan ajar lain yang secara khusus memperdalam tema Yesus sebagai locus classicus Sakramen Penguatan. Dengan demikian pemikiran Kenan B. Osborne dalam terang ajaran Gereja Katolik, yuridis, dan pastoral inipun merupakan sumbangan berharga bagi teologi sakramen di zaman sekarang. Bagi penulis, pemikiran Kenan B. Osborne ini memberikan masukan yang berharga dalam perkembangan teologi Sakramen Penguatan. Dengan memasukkan tema "Yesus sebagai locus classicus Sakramen Penguatan" di dalam materi katekese persiapan penerimaan Sakramen Penguatan, fokus atau poin pemahaman yang diterima oleh para calon penguatan akan lebih lengkap dan mendasar. Pemikiran Kenan B. Osborne ini relevan dan membantu Gereja untuk semakin memahami dan memperdalam makna Sakramen Penguatan serta sekaligus memberikan refleksi iman untuk semakin dekat dengan Yesus sebagai sakramen Allah. 


\section{CATATAN AKHIR}

1 Aloysius Soenarto, Katekese bagi Calon Krisma - Buku Pembina (Yogyakarta: Kanisius, 2002), 13.

2 Surat Apostolik Divinae Consortium Naturae dipromulgasikan oleh Paus Paulus VI pada 15 Agustus 1971.

Sebagai catatan, dalam tulisan ini penulis menggunakan kata "Yesus sebagai locus classicus" yang mana mengacu pada diri Yesus secara utuh, yaitu hidup, sengsara, wafat dan kebangkitan-Nya. Kata "Yesus sebagai locus classicus" ini merupakan kekhasan dari pemikiran Kenan B. Osborne.

4 Di dalam bukunya ia menulis demikian: He is the one in whom the Spirit resides. Just as we noted in the chapter on baptism that Jesus is the baptized, so too we can say, even though the use of the term as far as the time of Jesus is concerned is anachronistic, that Jesus is the confirmed. Whatever confirmation as a sacrament intends to proclaim, it is to be found in Jesus, the locus classicus of what the sacrament of confirmation is all about. It was also noted above that Jesus is to be seen as the primordial sacrament in such a way that the individual sacraments are constituted as sacraments because of their relationship to this primordial sacrament. Kenan B. Osborne, The Christian Sacraments of Initiation: Baptism, Confirmation, Eucharist (New York: Paulist Press, 1987), 129.

5 Kenan B. Osborne, Sacramental Theology: A General Introduction (New York: Paulist Press, 1988), 88.

$6 \quad$ E. Martasudjita, Sakramen-Sakramen Gereja (Yogyakarta: Kanisius, 2003), 86.

7 Kenan B. Osborne, The Christian Sacraments of Initiation: Baptism, Confirmation, Eucharist, 129-130.

8 Kenan B. Osborne, Sacramental Theology: A General Introduction, 31

9 Kenan B. Osborne, Sacramental Theology: A General Introduction, 137-138.

10 Kenan B. Osborne, The Christian Sacraments of Initiation: Baptism, Confirmation, Eucharist, 129.

11 Kenan B. Osborne, Sacramental Theology: A General Introduction, 76-78.

12 C. Groenen, Teologi Sakramen Inisiasi Baptisan-Krisma (Yogyakarta: Kanisius, 1992), 20

13 C. Groenen, Teologi Sakramen Inisiasi Baptisan-Krisma, 21.

14 Kenan B. Osborne, Sacramental Theology: 50 Years After Vatican II (Florida: Lectio Publishing, 2014), 34

15 Kenan B. Osborne, The Christian Sacraments of Initiation:

\section{DAFTAR RUJUKAN}

Alkitab. Jakarta: Lembaga Alkitab Indonesia, 2009 ,

Dokumen Konsili Vatikan II diterjemahkan oleh R. Hardawiryana. Jakarta: Obor, 2012.

Dupuis, Jacques (ed.). The Christian Faith in the Doctrinal Documents of The Catholic Church. Bangalore: Theological Publication in India, 1995.

Groenen, C. Teologi Sakramen Inisiasi Baptisan-Krisma. Yogyakarta: Kanisius, 1992.

Groenen, C. "Sakramen-Sakramen Inisiasi Kristen: Baptis dan Krisma", dalam J.B. Banawiratma (ed.), Baptis-Krisma-Ekaristi. Yogyakarta: Kanisius, (1989): 77-110.
Baptism, Confirmation, Eucharist, 101.

16 E. Martasudjita, Sakramen-Sakramen Gereja, 247.

17 C. Groenen, "Sakramen-Sakramen Inisiasi Kristen: Baptis dan Krisma”, dalam J.B. Banawiratma (ed.), Baptis-Krisma-Ekaristi (Yogyakarta: Kanisius, 1989), 95.

18 DS 1317: The second sacrament is confirmation; its matter is the chrism prepared from the oil, which signifies the excellence of conscience, and from the balsam, which signifies the fragrance of a good reputation, and is blessed by a bishop. The form is: I sign thee with the sign of the cross and I confirm thee with the chrism of salvation, in the name of the Father and of the Son and of the Holy Ghost. Jacques Dupuis (ed.), The Christian Faith in the Doctrinal Documents of The Catholic Church (Bangalore: Theological Publication in India, 1995), 545.

19 DS 1629: If anyone says that those who ascribe any power to the sacred chrism of confirmation are offending the Holy Spirit, anathema sit. Jacques Dupuis (ed.), The Christian Faith in the Doctrinal Documents of The Catholic Church, 549.

20 E. Martasudjita, Sakramen-Sakramen Gereja, 249.

21 SC 71: Upacara Krisma hendaknya ditinjau kembali juga supaya lebih nampak jelas hubungan erat Sakramen itu dengan seluruh inisiasi kristiani. Maka dari itu pembaharuan janji-janji Baptis seyogyanya mendahului penerimaan Sakramen Krisma. Kanon 842 \$2: Sakramen-sakramen Baptis, Penguatan dan Ekaristi Mahakudus terjalin satu sama lain, sedemikian sehingga dituntut untuk inisiasi kristiani yang penuh.

22 Secara teologis harus dikatakan bahwa Roh Yesus dan Roh Kudus adalah dua Pribadi yang berbeda, yakni Pribadi Kedua dan Pribadi Ketiga dalam Allah Tritunggal. Dengan kata lain, keidentikan di sini bukanlah keidentikan diri Pribadi, yang mana seolah-olah Pribadi Kristus dan Pribadi Roh Kudus itu sama saja, sebab sejatinya Kristus dan Roh Kudus itu Pribadi Ilahi yang berbeda. Adapun pemahaman yang tepat ialah keidentikan di sini merujuk pada keidentikan karya. Artinya, baik karya Roh Kristus dan karya Roh Kudus adalah satu dan sama, satu karya Allah Trinitas, karya ketiga Pribadi Allah Tritunggal sekaligus, satu dan sama. Lih. E. Martasudjita, Pokok-Pokok Iman Gereja: Pendalaman Teologis Syahadat (Yogyakarta: Kanisius, 2013), 218.

23 C. Groenen, Teologi Sakramen Inisiasi Baptisan-Krisma, 100 .
Komisi Kateketik Keuskupan Agung Semarang. Katekese Inisiasi: Gagasan Dasar dan Silabus. Yogyakarta: Kanisius, 2012.

Leo XIII. "Divinum Illud Munus", tersedia dari http:// w2.vatican.va/content/leo-xiii/en/encyclicals/ documents/hf_l-xiii_enc_09051897_divinum-illud-munus.html; diakses 28 Maret 2018.

Mariyanto, Ernest. Persiapan Krisma Suci. Kanisius, Yogyakarta, 1987.

Martasudjita, E. Sakramen-Sakramen Gereja: Tinjauan Teologis, Liturgis, dan Pastoral. Yogyakarta: Kanisius, 2003.

Martasudjita, E. Pokok-Pokok Iman Gereja: Pendalaman Teologis Syahadat. Yogyakarta: 
Kanisius, 2013.

Osborne, Kenan B. The Christian Sacraments of Initiation: Baptism, Confirmation, Eucharist. New York: Paulist Press, 1987.

Osborne, Kenan B. Sacramental Theology: A General Introduction. New York: Paulist Press, 1988.

Osborne, Kenan B. Sacramental Theology: 50 Years After Vatican II. Florida: Lectio Publishing, 2014.

Paulus VI. Divinae Consortium Nature, 15 Agustus 1971, dalam AAS, 63 (1971): 657-664.
Rubiyatmoko, Robertus (Ed). Kitab Hukum Kanonik. Jakarta: Konferensi Waligereja Indonesia, 2016.

Soenarto, Aloysius. Katekese bagi Calon Krisma - Buku Pembina. Yogyakarta: Kanisius, 2002.

Yohanes Paulus II. "Dominum et Vivificantem, tersedia dari http://w2.vatican.va/content/ john-paul-ii/en/encyclicals/documents/ hf_jp-ii_enc_18051986_dominum-et-vivificantem.html; diakses 28 Maret 2018. 